\title{
Fault-Related Folding in California's Northern Channel Islands Documented by Rapid-Static GPS Positioning
}

\author{
Nicholas Pinter, Geology Department, \\ Southern Illinois University, \\ Carbondale, IL 62901-4324, USA, \\ npinter@geo.siu.edu
}

Bjorn Johns, UNAVCO, 3340 Mitchell Lane, Boulder, CO 80301, USA, bjorn@unavco.ucar.edu

\author{
Brandy Little, Geology Department, \\ Southern Illinois University, \\ Carbondale, IL 62901-4324, USA, \\ blittle@siu.edu
}

\section{W. Dean Vestal, Geology Department, Southern Illinois University, Carbondale, IL 62901-4324, USA, vestal@siu.edu}

\section{ABSTRACT}

Rapid-static Global Positioning System positioning was used to measure late Quaternary deformation of uplifted coastal terraces on Santa Rosa and San Miguel Islands, which have accumulated regional warping and local faulting over 100+ k.y. Late Quaternary deformation on Santa Rosa is sharply partitioned, with several hundred meters of surfacerupturing left slip, but $15+\mathrm{m}$ of vertical motion taken up by folding, resulting in anticlinal growth of at least $0.12 \mathrm{~m} / \mathrm{k} . \mathrm{y}$. Deformation on San Miguel Island to the west is consistent with warping on the north limb of the regional anticlinal structure. Deformation on both islands matches activity to the east, suggesting that the Santa Rosa Island fault represents an en echelon segment of the larger Transverse Ranges Boundary fault system and the Northern Channel Islands antiform. The Northern Channel Islands have been the focus of a debate over differing geometrical models of fault-related folding, and the deformation measurements presented here suggest that uplift of the islands is occurring over a smoothly curved thrust ramp rather than a fault-bend fold. This reinterpretation is important, as current earthquake-hazard assessments on this and other buried reverse faults depend entirely on assumptions unique to the fault-bend fold geometry. We suggest that alternative models should be considered where geologically reasonable, and that surface uplift measurements across fault-related folds can provide a crucial test of subsurface geometry.

\section{INTRODUCTION}

Especially since the 1994 Northridge earthquake, buried reverse faults have been the target of intensive research. In southern California and elsewhere, the locations of these structures, their geometry at depth, and rates and histories of slip are based primarily on balanced cross sections utilizing the fault-bend-fold and fault-propagationfold models (e.g., Shaw et al., 1994). Because so much crucial information is model specific, there have been rumblings of doubt about the widespread application of these models without independent corroboration (e.g., Ramsay, 1992; Stone, 1996). Our work in the Northern Channel Islands

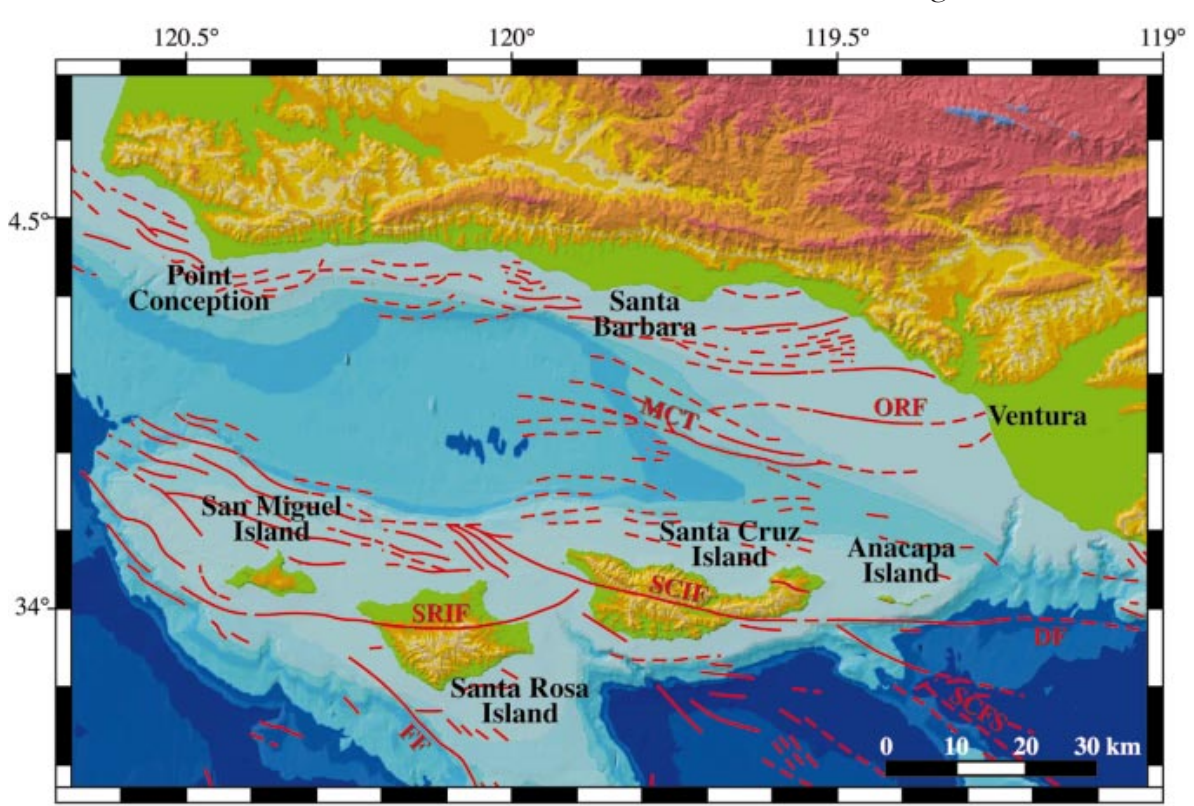

Figure 1. The Northern Channel Islands form the southern margin of the Santa Barbara Channel. Faults are from Jennings (1994). DF-Dume fault; FF-Ferrilo fault; MCT_ Mid-Channel trend; ORF_-Oak Ridge fault; SCFS—San Clemente fault system; SCIF-Santa Cruz Island fault; SRIF_-Santa Rosa Island fault. Digital topography is from U.S. Geological Survey digital elevation models, and bathymetry is from National Oceanic and Atmospheric Administration data, compiled by L. Mertes, Department of Geography, University of California, Santa Barbara. has focused largely on using surface deformation measurement to test subsurface models of fault-related folding.

Precise positioning using the Global Positioning System (GPS) has revolutionized investigations of (University NAVSTAR Consortium, 1998). Data collection of $\geq 24-48$ hours per site can yield precisions of a few millimeters in measurements of intersite baseline distances. In contrast, this project used the same geodetic-quality GPS equipment as a high-precision surveying tool, sacrificing roughly an order of magnitude of precision for rapidacquisition capability and results forthcoming in a single field season. Unlike geodynamic GPS studies, which directly measure tectonic motion over a few years, we measured "fossil" strain accumulated on uplifted coastal terraces over periods of $\sim 10^{5} \mathrm{yr}$.

\section{Setting}

The Northern Channel Islands (Fig. 1) form the southern margin of the Santa geodynamics and crustal deformation 
Barbara Channel and the southernmost range of the western Transverse Ranges. This area is a natural laboratory for examining neotectonic processes that include: (1) complex and partitioned strain; (2) fault-related fold growth; and (3) fault activity that threatens the local area, including Los Angeles. Two active left-lateral faults cut the islands-the Santa Rosa Island fault (Colson, 1996) and the Santa Cruz Island fault (Pinter and Sorlien, 1991). These faults appear to be continuous with similar faults along the northern margin of the Los Angeles Basin, together forming a semicontinuous zone which has been called the Transverse Ranges Boundary fault zone (Pinter et al., 1998). These surface-rupturing faults seem to coexist with low-angle thrust faults at depth (e.g., Shaw and Suppe, 1994; Rivero et al., 2000). Regional thrust structures have been inferred beneath the Santa Monica Mountains (Davis and Namson, 1994; Dolan et al., 1994) and beneath the Northern Channel Islands (the Channel Islands thrust; Shaw and Suppe, 1994). It has been suggested that uplift of the Northern Channel Islands chain is the result of south-vergent slip across a north-dipping ramp in the underlying thrust fault (Shaw and Suppe, 1994; Seeber and Sorlien, 2000). The Northern Channel Islands antiform itself has been interpreted either as a classic fault-bend fold (Shaw and Suppe, 1994) or as the expression of horizontalaxis rotation above a listric-shaped thrust fault (Seeber and Sorlien, 2000). Importantly, each fold model predicts a different magnitude or rate of slip on the causative fault and hence a different earthquake hazard.

\section{Study Area}

This research was conducted on San Miguel and Santa Rosa Islands. San Miguel is the westernmost island in the chain. More than $3000 \mathrm{~m}$ of Cretaceous to Miocene sedimentary and volcanic rocks are exposed on San Miguel (Weaver and Doerner, 1969). Although traversed by a few faults, no recent slip has been demonstrated on the island. Inland of the sea cliffs that ring San Miguel, the interior has only subdued relief, consisting mainly of uplifted terraces deeply mantled by relict and active sand dunes. On Santa Rosa
Island, $2000 \mathrm{~m}$ of Eocene to Miocene sedimentary and volcanic rocks are exposed (Dibblee and Ehrenspeck, 1998). The Tertiary sequence is overlain by diverse late Quaternary deposits, especially dune sand, which reaches thicknesses of $\geq 50 \mathrm{~m}$ (Woolley, 1998). Coastal terraces fringe Santa Rosa and form a broad bench across much of the northern half of the island (Orr, 1960). A uranium-series date of $120 \pm 3$ k.y., equivalent to oxygen-isotope substage $5 \mathrm{e}$, has been obtained from solitary corals on the second lowest terrace (Thorup, 1994), and this age has been reconfirmed by independent U-Th analysis (J. Lundberg, 2000, pers. comm.).

The most prominent tectonic feature of Santa Rosa Island is the Santa Rosa Island fault. Displacement of Miocene rocks across the Santa Rosa Island fault suggests at least $16 \mathrm{~km}$ of left slip on this fault (Weaver, 1969), and more recent motion is indicated by drainages deflected several hundred meters to the left (Colson, 1996). There has been some disagreement about the degree of latest Quaternary activity on the Santa Rosa Island fault. Suggestions of relatively rapid $(\sim 1 \mathrm{~mm} / \mathrm{yr})$ and recent slip ( $\geq 2$ ruptures in the past 20 k.y.) and large earthquake hazard (up to M 7.7; Colson, 1996) are difficult to reconcile with other observations, including the eastern sea cliff exposure of the fault, which shows little or no vertical separation across the stage 5e terrace platform (e.g., Sorlien, 1994).

\section{GPS POSITIONING}

Several different GPS approaches are available that vary in precision, application, and equipment cost over several orders of magnitude. Since the cessation of military signal degradation in May 2000, handheld GPS receivers yield position accuracies within $\pm 20 \mathrm{~m}$ in the horizontal and $\pm 40 \mathrm{~m}$ in the vertical. Sources of error include atmospheric effects on the satellite signal, clock errors, and orbital uncertainties. Much of this uncertainty can be reduced using differential positioning, in which two or more receivers are operated simultaneously with one as a stationary base station, yielding meter-level precision with postprocessing. To further increase precision, especially on baselines $>5$ $\mathrm{km}$, dual-frequency GPS receivers record both the L1 (1227.6 MHz) and L2 (1575.42 MHz) signals in order to remove ionospheric errors.

To achieve the cm-level precision required for most survey applications, GPS carrier-phase data must be used. Receivers that utilize phase data record not only the code from each satellite but also the phase of each incoming signal. In postprocessing GPS phase data, the software must find a unique or fixedinteger solution for the number of carrier-wave cycles for each satellite signal. The resulting level of precision depends largely on the duration of continuous measurements at a site. Rapid-static GPS positioning (Blewitt, 1990) refers to the mode of operation in which one collects the minimum data necessary_as little as $\sim 10 \mathrm{~min}$ of measurement - to obtain a fixed-integer carrier-phase solution. For the equipment used here, vertical precision is estimated at $1.0 \mathrm{~cm}$ plus one part per million times baseline length (Trimble Navigation, 1998), suggesting that all elevations measured on Santa Rosa and San Miguel were precise to $2.8 \mathrm{~cm}$ or better relative to the local base station. Adding this uncertainty to the uncertainty in the local geoid variations, all elevation measurements in the study area should be accurate to better than 5 $\mathrm{cm}$, and all horizontal coordinates accurate to better than $2.5 \mathrm{~cm}$.

Although the rapid-static GPS measurement times were $\sim 150-300$ times shorter than for campaign GPS, the positions were only about 5-10 times less precise. This work extended research from the previous 2-3 years on Santa Cruz and Anacapa Islands using ground-based laser surveying. In a single field season, the new GPS-based field work more than doubled the previous data coverage, with precisions equal to or better than the ground-based measurements. The principal advantage of GPS surveying is that it does not require line of sight between measurement points, allowing for much more rapid data acquisition. Another GPS-based alternative is real-time kinematic surveying, which provides real-time differential correction to the roving receiver, although real-time kinematic coverage can be limited in rugged terrain. 
On both islands, we used a Trimble 4700 18-channel dual-frequency GPS receiver as the local base station. Two additional dual-frequency receivers (Trimble 4800s) were placed on the terrace points. Although several sites provided as little as 40\% sky visibility due to sea cliffs, fixed-integer solutions were obtained at all locations. A total of 139 GPS baselines were measured-102 on Santa Rosa Island and 37 on San Miguel. After the field surveys, basestation data from the two islands were processed using NASA's AutoGIPSY service, producing 3-dimensional basestation coordinates in the 1996 International Terrestrial Reference Frame (ITRF-96). We then processed the baselines between the local base stations and the rover sites using Trimble GPSurvey software.

\section{COASTAL TERRACES}

In tectonically active coastal settings, uplifted coastal terraces are valuable markers for assessing the presence, pattern, and rates of late Quaternary deformation. Erosional coastal terraces (Fig. 2) consist of three principal elements: a wave-cut platform, a sea cliff, and an inner edge (or shoreline angle). Coastal terraces form during glacial-interglacial eustatic highstands, and the inner edge marks the highest position of sea level associated with a given highstand. The nature, number, ages, and spacing of terraces on an uplifting coastline depend on the coastal

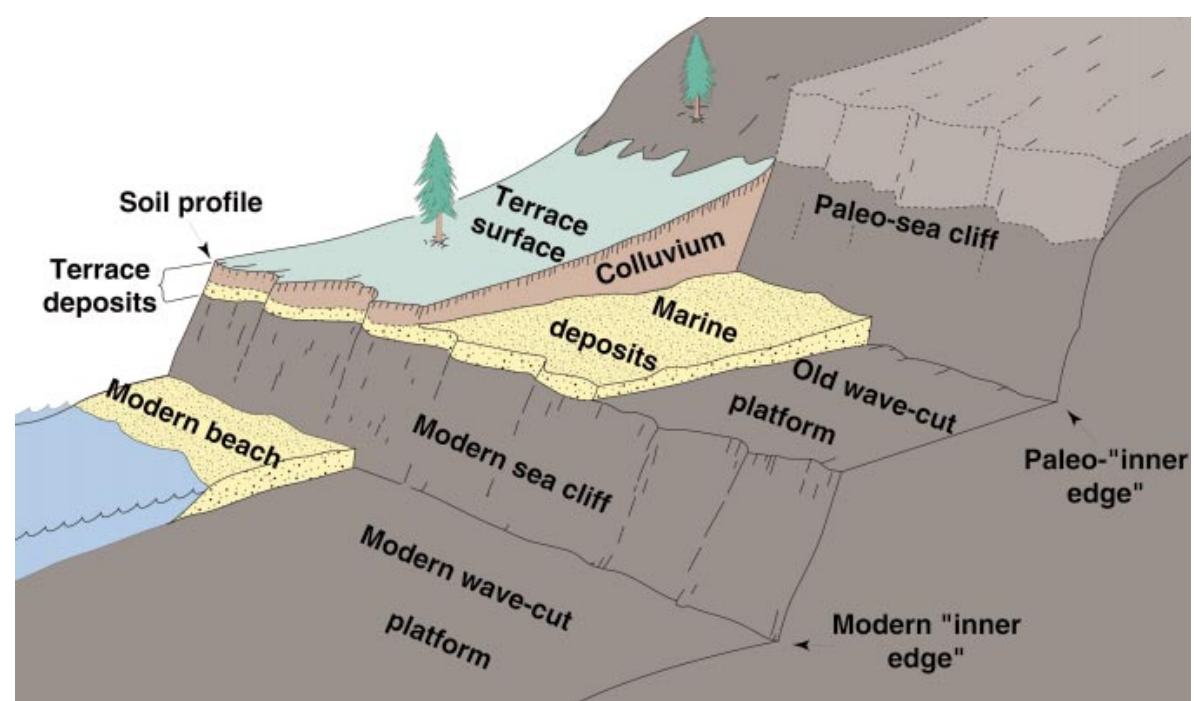

Figure 2. Characteristic morphology of uplifted wave-cut coastal terraces (after Hanson et al., 1990, Guidebook, Friends of the Pleistocene, Pacific Cell, Fall Field Trip). processes active there, the rate of tectonic uplift, and the nature and strength of surface processes that act to erode or otherwise obscure the relict terraces over time (Keller and Pinter, 2001). Terrace inner edges represent vertical datums, with the present-day elevation of a paleo-inner edge, relative to the sea level at which it formed, equal to the magnitude of tectonic uplift since terrace formation. Each uplifted coastal terrace acts as a geomorphic timeline for any active structure that crosses that surface, providing morphological and stratigraphic markers with which to measure the timing and average rates of deformation.

\section{FIELD MEASUREMENTS AND ANALYSIS}

In addition to GPS positioning, we mapped the terrace distribution on the two islands. Initial terrace maps were created using 1:40000 stereo air photographs. The annotated photos were scanned, registered to the U.S. Geological Survey (USGS) digital orthoquadrangles and orthorectified using PCI Orthoengine software. The resulting orthoimage is an undistorted photographic map of the study area, including terrace features, upon which we could automatically overlay our GPS measurements. We mapped three distinct terrace levels on San Miguel Island and five on Santa Rosa (Figs. 3 and 4). The lowest level on both islands, $\mathrm{T} 1$, occurs as an irregular notch or 
$z_{\mathrm{WCP}}$, is:

$z_{\mathrm{SLA}}=z_{\mathrm{WCP}}+d \tan \alpha$

where $\alpha$ is the platform slope and $d$ is the orthogonal distance between that point and its associated inner edge. Platform slopes were estimated by measuring trios of terrace points and solving for strike and dip using numerical three-point solutions. The distance $d$ was measured from the terrace orthomaps as the shortest path between each point and the base of its associated paleo-sea cliff. Error ranges were calculated as the sum of the $1 \sigma$ standard deviation for platform slope and the GPS measurement uncertainty.

\section{Terrace Profiles}

Projecting terrace elevations onto a cross section (Fig. 6), deformation is

Figure 4 (below). Terrace map and GPS points on Santa Rosa Island. Vectors illustrate elevations of points measured at terrace inner edges and on the wave-cut platforms. Note that the T1 and T2 vectors use a different scale (left) than do the T3 and T4 vectors. Platform elevations shown here are raw elevations, unadjusted for slope and distance to the corre-sponding inner edge.

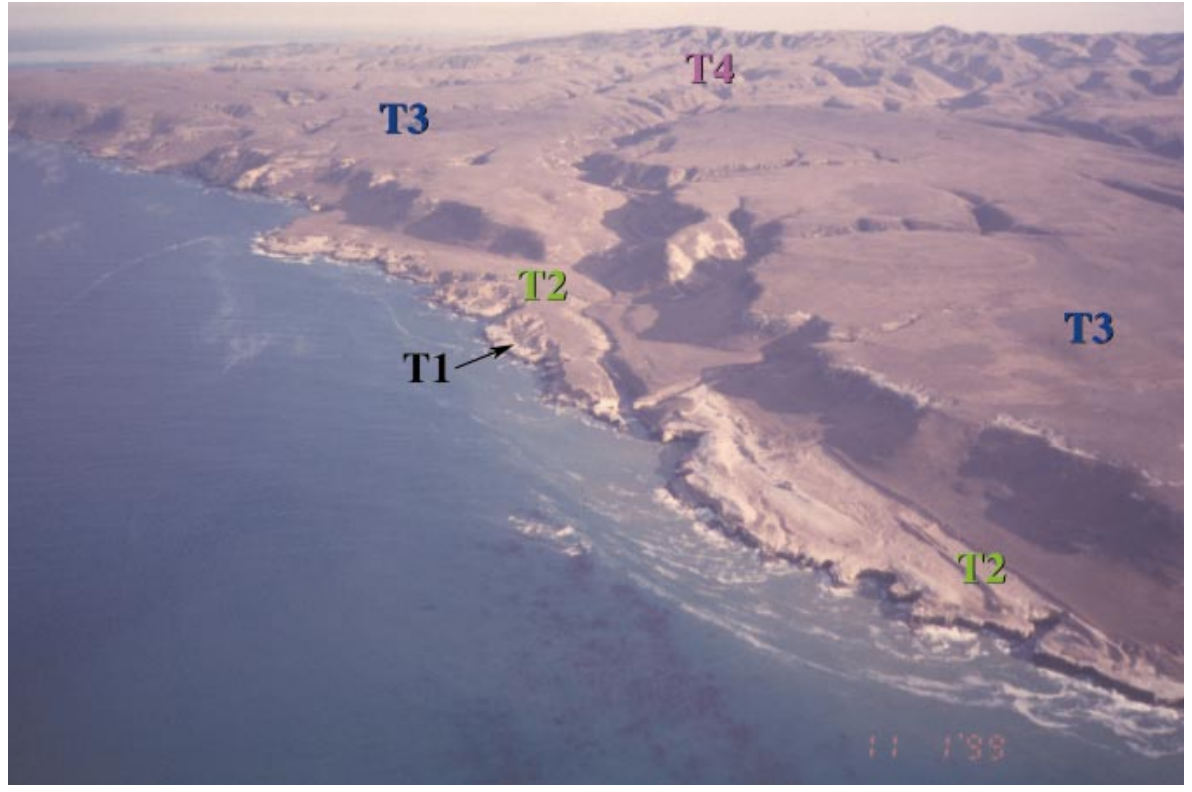

Figure 3. The northwest coast of Santa Rosa Island, looking east. Four terrace levels are shown. Although the surfaces look smooth at this scale, the older terraces are mantled by eolian sand that reaches $50 \mathrm{~m}$ in thickness and largely obscures the underlying morphology.

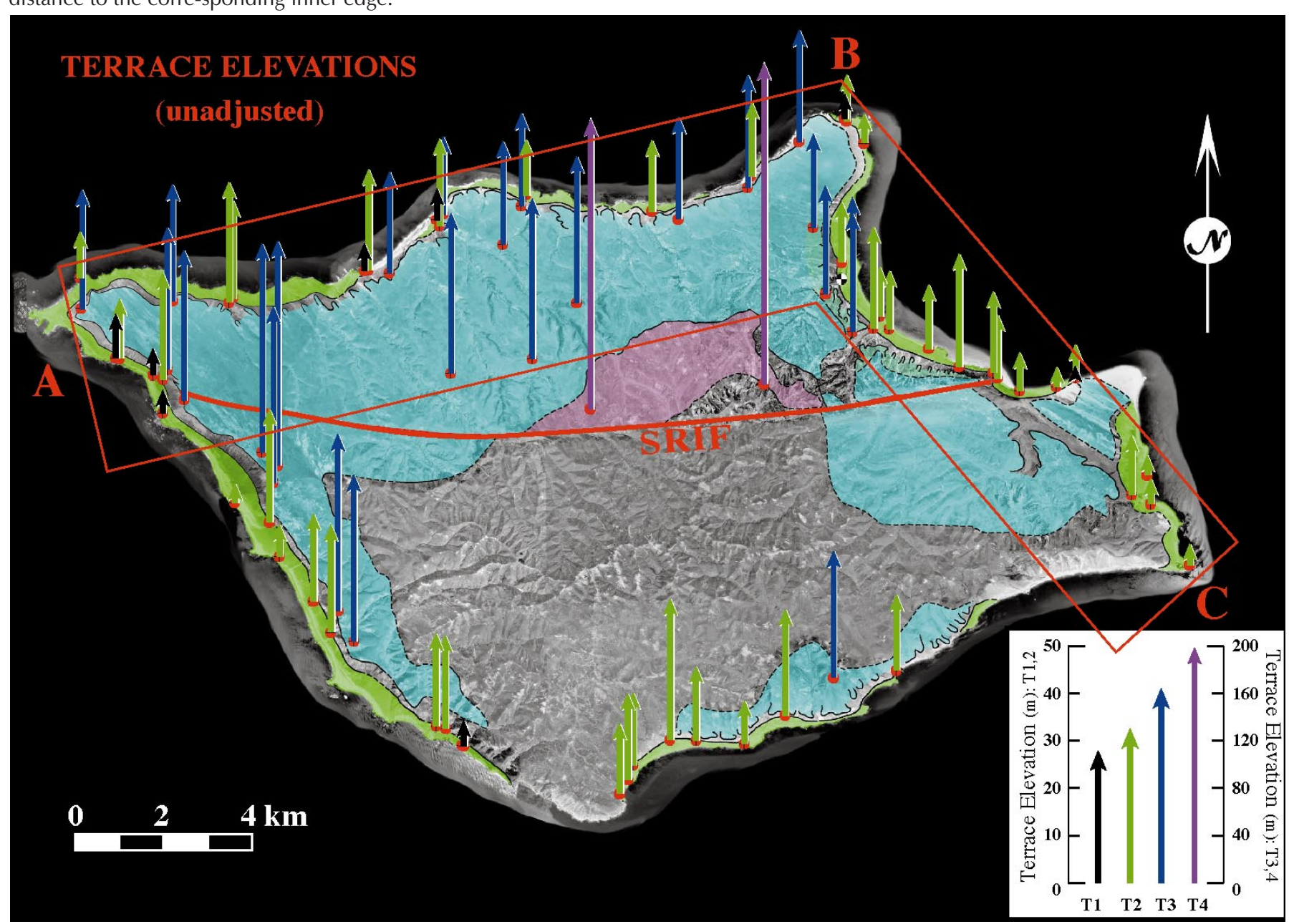


indicated by variations in the elevation of terrace inner edges. On Santa Rosa Island, the $\sim 125$ ka T2 terrace level provided the best tectonic datum, probably because it falls within a critical age window: young enough to be well and widely preserved but old enough to have accumulated tectonic warping that is large relative to the measurement uncertainty. The T2 surface has been anticlinally warped over the Santa Rosa Island fault. The anticline is asymmetrical, with a steep south limb and a gentler north limb. A smooth curve can be fit to the measured T2 points, and scaled versions of this curve also fit the T1 and T3 measurements (Fig. 6). The points on those other terraces alone are too sparse and, on the $\mathrm{T} 3$ terrace, the error bars too large to clearly demonstrate the pattern of deformation, but every point measured on Santa Rosa is consistent with the pattern measured on the T2 terrace.

\section{DISCUSSION}

Precise measurement of the pattern and rates of late Quaternary deformation across Santa Rosa Island has a number of tectonic implications, both local and regional. Locally, the GPS measurements illustrate that slip on the Santa Rosa Island fault is strongly partitioned, with the strike-slip component of motion manifested at the surface by severalhundred-meter drainage deflections, but the vertical component going blind at shallow depth and absorbed by folding.

A more regional question is how the Santa Rosa Island fault fits into the pattern of deformation along the southern margin

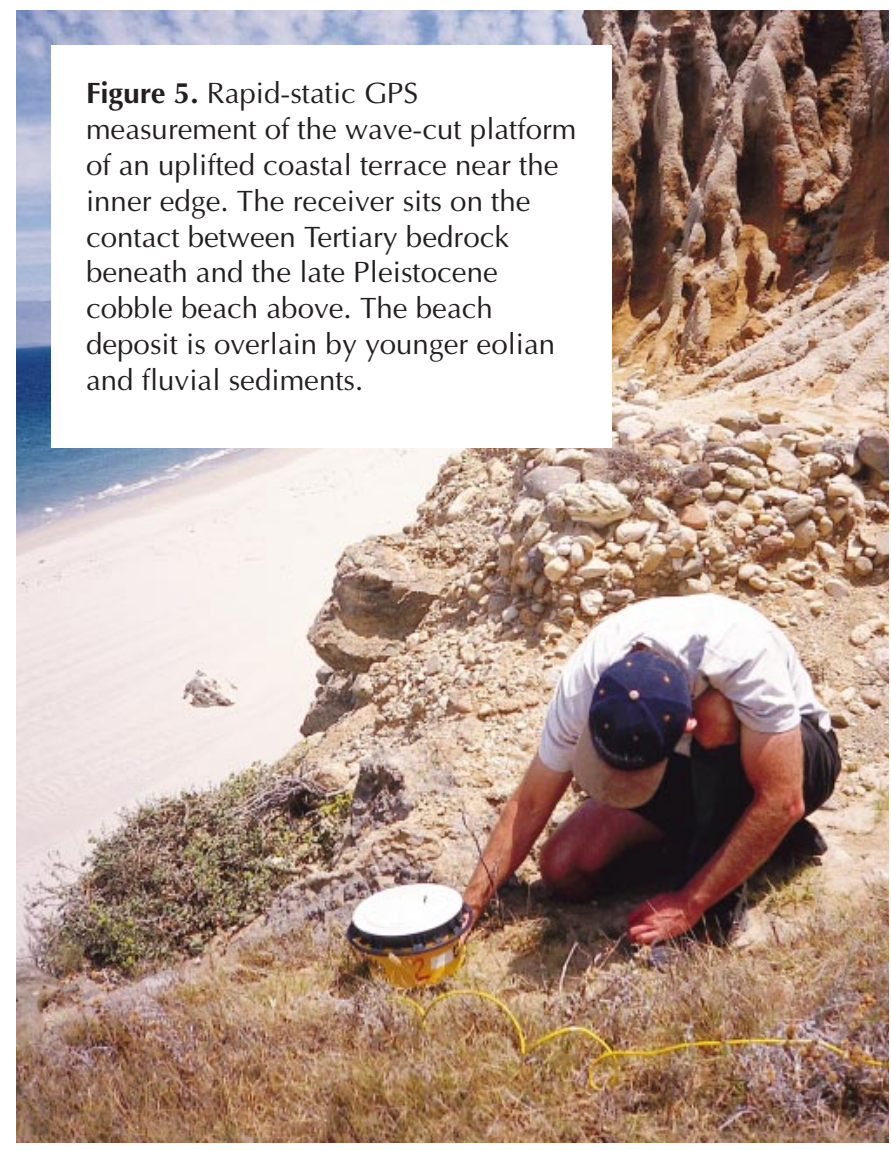

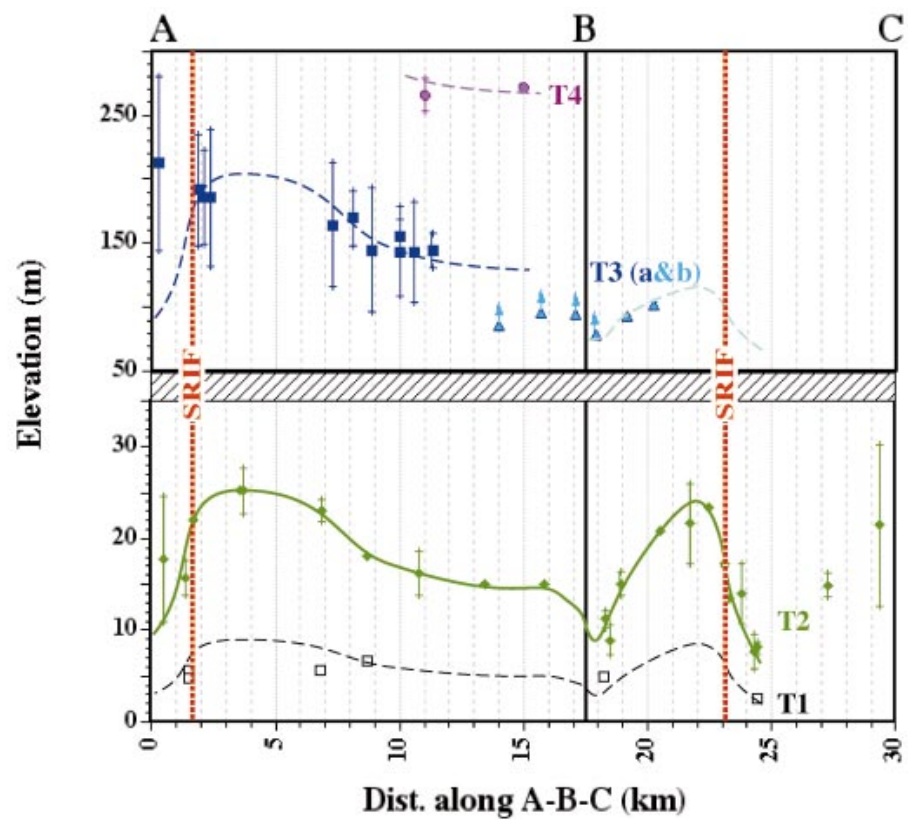

Figure 6. Cross-sectional profile A-B-C on Santa Rosa Island (see Fig. 3) showing corrected terrace elevations. SRIF shows the locations of the Santa Rosa Island fault. Error bars are the sum of the $\pm 1 \sigma$ uncertainties in wave-cut platform slope and the GPS measurement errors. Note the change in vertical exaggeration between the lower and upper plots. The green curve was qualitatively fit to the $\mathrm{T} 2$ data in order to create the smoothest possible curve that conforms to all points; other curves are scaled versions of the T2 curve. Point spacing is too coarse and error bars too large on the other levels to show deformation details, but the scaled curves show that every measured point is consistent with the pattern measured on T2.

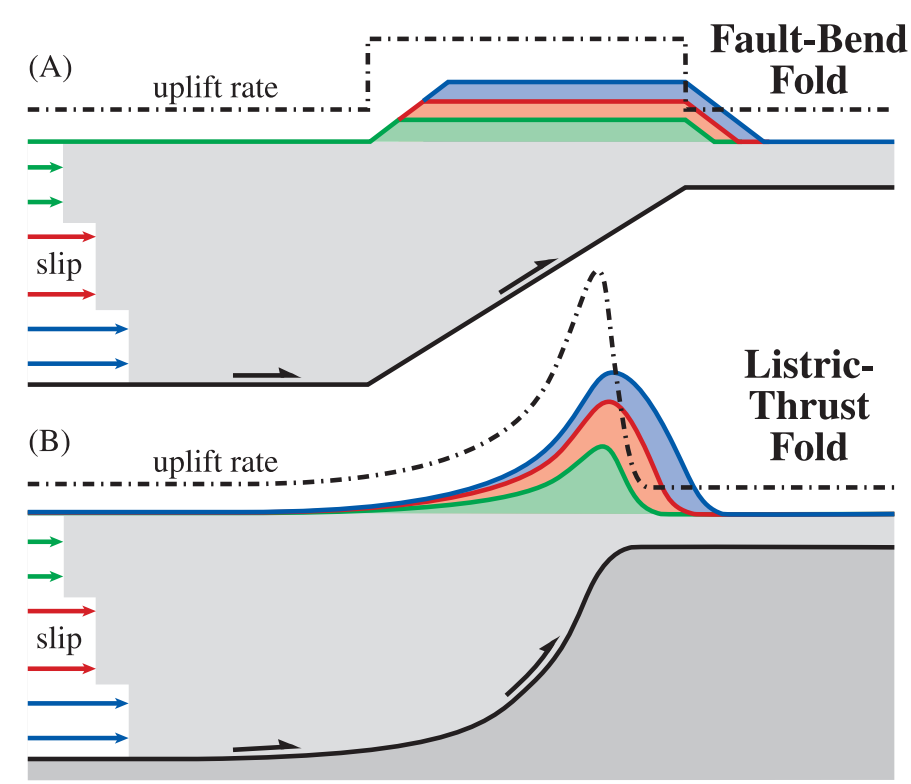

Figure 7. Modeled profiles for three terrace levels (green, red, blue) on (A) a fault-bend fold, and (B) a fold generated above a listric thrust. Uplift rate is proportional to dip on the underlying fault, so that the planar fault ramp uplifts the overlying terraces at a uniform rate, except in narrow zones above the fault kinks. In contrast, a listric thrust ramp results in a smoothly varying uplift-rate profile capable of creating the uplifted coastal terraces measured in the Northern Channel Islands. 
of the western Transverse Ranges. The pattern of fault slip and warping on Santa Rosa Island closely matches late Quaternary deformation on Santa Cruz Island to the east. Like the Santa Rosa Island fault, the Santa Cruz Island fault dips steeply to the north, with broad late Quaternary anticlinal uplift north of the fault (Pinter et al., 1998). Both folds are 4-5 km wide, measured perpendicular to the faults, and strongly asymmetrical, with very steep gradients on their south sides. The rates of left slip on the two faults also are similar $(0.75 \mathrm{~mm} / \mathrm{yr}$ on Santa Cruz versus $\sim 1 \mathrm{~mm} / \mathrm{yr}$ on Santa Rosa), as are the vertical rates of foldcrest uplift (0.1-0.2 mm/yr). These similarities are somewhat surprising because the Santa Rosa Island fault is sharply oblique to the trend of the family of left-oblique faults at the margin of the Transverse Ranges (Fig. 1). We suggest that the Santa Rosa Island fault represents a step-over and the westward extension of the Transverse Ranges Boundary fault zone. Such step-overs in anticlinal axes are documented in a number of locations (e.g., Burbank, 1999), with slip declining along strike on one segment as it picks up on the other. This interpretation is supported by northward tilting of San Miguel Island, confirming that anticlinal deformation follows the trend of the Santa Rosa Island fault westward.

Perhaps the broadest implication of deformation measured on Santa Rosa and San Miguel islands is that, like on Santa Cruz Island to the east (Seeber and Sorlien, 2000), surface uplift rates increase smoothly from north to south up the backlimb of the Northern Channel Islands antiform. This is significant because the fault-bend-fold model that is most widely applied predicts uniform uplift rates above individual fault panels defined by discrete kinks (Fig. 7). The smooth anticlinal warping measured here is inconsistent with a fault-bend-fold model for the Northern Channel Islands. Any fault-bend-fold interpretation can be retroactively fit to varying uplift by inserting as many additional kinks as needed, but we suggest that the listricthrust model provides a simpler and more robust solution. Furthermore, although folds characterized by discrete kink bands have been unequivocally documented in many locations, smoothly curved thrust ramps are also geologically reasonable in some settings. Listric shaped thrust faults may be reasonable where strain has reoriented over time, and preexisting normal faults have been reactivated as thrusts. The southern California margin experienced widespread and significant extension in the Miocene (Yeats, 1987), and many Miocene extensional faults have been identified (Seeber and Sorlien, 2000). We do not suggest discarding all fault-bendfold and fault-propagation-fold interpretations, but rather we advocate considering alternative models where they may be geologically reasonable. A broad variety of tools, including measurement of coastal terraces, is available for measuring surface uplift, and this surficial data may provide a vital test for corroborating subsurface fault geometry and verification of fault slip and earthquake hazard assessments that are derived from these models.

\section{ACKNOWLEDGMENTS}

GPS support was provided by the University NAVSTAR Consortium (UNAVCO; www.unavco.ucar.edu), a consortium of more than 100 universities and laboratories that provides project support to National Science Foundation-funded and NASAfunded investigators. Logistical support was provided by Channel Islands National Park, and we thank Sarah Chaney in particular for all her help. We also thank Ramon Arrowsmith, Karl Karlstrom, Eric Kirby, and John Weber for very thorough reviews of this paper.

\section{REFERENCES CITED}

Blewitt, G., 1990, A new tool for dense monitoring of crustal strain: GPS rapid-static surveying: Eos (Transactions, American Geophysical Union), v. 71, p. 483.

Burbank, D.W., McLean, J.K., Bullen, M., Abdrakhmatov, K.Y., and Miller, M.M., 1999, Partitioning of intermontane basins by thrust-related folding, Tien Shan, Kyrgyzstan: Basin Research, v. 11, p. 75-92.

Colson, K.B., 1996, Neotectonics of the left-lateral Santa Rosa Island fault, western Transverse Ranges, southern California [M.S. thesis]: San Diego, California, San Diego State University, $92 \mathrm{p}$.

Davis. T.L., and Namson, J., 1994, A balanced cross section of the 1994 Northridge earthquake, southern California: Nature, v. 372, p. 167-169.

Dolan, J.F., Sieh, K., Rockwell, T.K., Yeats, R.S., Shaw, J., Suppe, J., Huftile, G.J., and Gath, E.M., 1994, Prospects for larger or more frequent earthquakes in the Los Angeles metropolitan region: Nature, v. 267, p. 199-205.

Dibblee, T.W. Jr., and Ehrenspeck, H.E., 1998, General geology of Santa Rosa Island, California, in Weigand, P.W. ed., Contributions to the geology of the Northern Channel Islands, southern California: Bakersfield, California, Pacific
Section, American Association of Petroleum Geologists, MP-45, p. 49-75.

Jennings, C.W., 1994, Fault activity map of California and adjacent areas with locations and ages of recent volcanic eruptions: California Division of Mines and Geology, Geologic Data Map no. 6, scale 1:750 000.

Keller, E.A., and Pinter, N., 2001, Active tectonics: Earthquakes and landscape, 2nd edition: Upper Saddle River, New Jersey, Prentice-Hall, in press.

Orr, P.C., 1960, Late Pleistocene marine terraces on Santa Rosa Island, California: Geological Society of America Bulletin, v. 71, p. 1113-1120.

Pinter, N., and Sorlien, C., 1991, Evidence for latest Pleistocene to Holocene movement on the Santa Cruz Island fault, California: Geology, v. 19, p. 909-912.

Pinter, N., Lueddecke, S.B., Keller, E.A., and Simmons, K., 1998, Late Quaternary slip on the Santa Cruz Island fault, California: Geological Society of America Bulletin, v. 110, p. 711-722.

Ramsay, J.G., 1992, Some geometrical problems of rampflat thrust models, in McClay, K.R., ed., Thrust Tectonics: London, Chapman \& Hall, p. 191-200.

Rivero, C., Shaw, J.H., and Mueller, K., 2000, Oceanside and Thirtymile Bank blind thrusts: Implications for earthquake hazards in coastal southern California: Geology, v. 28, p. 891-894.

Seeber, L., and Sorlien, C.C., 2000, Listric thrusts in the western Transverse Ranges, California: Geological Society of America Bulletin, v. 112, p. 1067-1079.

Shaw, J.H., and Suppe, J., 1994, Active faulting and growth folding in the eastern Santa Barbara Channel, California: Geological Society of America Bulletin, v. 106, p. 607-626. Shaw, J.H., Hook, S.C., and Suppe, J., 1994, Structural trend analysis by axial surface mapping: American Association of Petroleum Geologists Bulletin, v. 78, p. 700-721.

Sorlien, C.C., 1994, Faulting and uplift of the Northern Channel Islands, California, in Halvorson, W.L., and Maender, G.J., eds., The fourth Channel Islands symposium: Update on the status of resources: Santa Barbara, California, Santa Barbara Museum of Natural History, p. 281-296.

Stone, D.S., 1996, Structural trend analysis by axial surface mapping: Discussion: American Association of Petroleum Geologists Bulletin, v. 80, p. 770-779.

Thorup, K., 1994, Deformation of marine terraces on Santa Rosa Island and implications for the activity of the Santa Rosa Island fault [senior thesis]: San Diego, California, San Diego State University, 19 p.

Trimble Navigation, 1998, 4800 Operation Manual: Sunnyvale, California, Trimble Navigation Ltd.

University NAVSTAR Consortium, 1998, UNAVCO brochure, www.unavco.ucar.edu/community/brochure/.

Weaver, D.W., 1969, Geology of the Northern Channel Islands, southern California borderland: Pacific Section, American Association of Petroleum Geologists Special Publication, 200 p.

Weaver, D.W., and Doerner, D.P., 1969, Lower Tertiary stratigraphy, San Miguel and Santa Rosa Islands, in Weaver, D.W., ed., Geology of the Northern Channel Islands, southern California borderland: Bakersfield, California Pacific Section, American Association of Petroleum Geologists Special Publication 200, p. 30-47.

Woolley, J.J., 1998, Aspects of the Quaternary geology of Santa Rosa Island, California, in Weigand, P.W., ed., Contributions to the Geology of the Northern Channel Islands, southern California: Bakersfield, California, Pacific Section, American Association of Petroleum Geologists, MP-45, p. 103-110.

Yeats, R.S., 1987, Changing tectonic styles in Cenozoic basins of southern California, in Ingersoll, R.V., and Ernst W.G., eds., Cenozoic basin development of coastal California: Englewood Cliffs, New Jersey, Prentice-Hall, Inc., $496 \mathrm{p}$.

Manuscript received November 30, 2000; accepted March 5, 2001. 